\title{
Training Services in Small and Medium-sized Enterprises: Evidence from Poland
}

\author{
Krzysztof Zieba and Malgorzata Zieba
}

Gdansk University of Technology

ul. Narutowicza 11/12, 80-233 Gdansk, Poland

cross $^{\text {ref }}$ http://dx.doi.org/10.5755/j01.ss.84.2.7492

\begin{abstract}
In the knowledge-based economy knowledge and skills are becoming more and more significant for the success of companies. This applies also to firms from small and medium-sized enterprises (SMEs) sector. As large companies in many cases posses special divisions devoted to trainings, they normally have no problems with updating the knowledge and skills of their employees. The situation is different with regard to SMEs, which often have no resources and abilities to train their employees. In the article, the following aspects are examined: 1 .What are the differences in demand for training services among firms from the SMEs sector and larger companies? 2. What are the determinants of making the decision about using particular training company and training topic?

This article analyses the characteristics of using training services by SMEs from the Pomeranian region of Poland and compares the results with those for larger companies.
\end{abstract}

Keywords: training services, skill development, small and medium-sized companies, Poland.

\section{Introduction}

Small and medium sized enterprises (SMEs) are becoming more and more significant in the European and global economies (e.g. Reid and Harris, 2002; Robertson, 2003; Al-Madhoun and Analoui, 2003; Kyriakidou and Maroudas, 2010). For example in the UK, SMEs constitute 99 percent of all the businesses and they stand for almost 50 percent of jobs (Gray, 2006). SMEs sector also contributes significantly to the success of the Polish economy (Zolnierski, 2009). Presently, SMEs constitute the majority of companies in most of the developed economies and they often hire the majority of the labour force. That is why there is a growing interest among researchers in SMEs functioning and the way they achieve success on the market.

In the knowledge-based economy well-educated and trained employees are a crucial factor for SMEs in achieving competitive advantage. Without appropriate training, the knowledge of employees might become obsolete and insufficient to carry out their tasks in efficient and effective manner. Training for SMEs might result in skills and competencies development (e.g. Johnston and Loader,
2003), which may further result in higher profitability (Huang, 2001).

The novelty of the article results from the following aspects. First of all, there is a lack of research on training services in SMEs in the Central Europe. Secondly, there is also not much research on the determinants of training services selection. In general, not so much attention has been paid to human resource management (HRM) in SMEs (Kyriakidou and Maroudas, 2010). One of the reasons for this is associating HRM with large companies which can afford such practices (Heneman, Tansky and Camp, 2000; Reid and Harris, 2002). Finally, there is not much evidence on differences with regard to sub-groups in SME sector (i.e. among micro, small and medium enterprises).

The research problem of the article is to examine the differences in demand for training services among firms from SMEs sector. Exploration of the problem is connected with examination on greater usage of training services by larger entities and on priorities given to various aspects of training services usage in the SME sector.

The aim of the article is to examine the hypotheses devoted to using training services by SMEs, i.e., to verify whether:

1. the probability of using training services increases alongside with the size of firms;

2. bigger businesses more often signal demand for major types of training services;

3. priorities given to various aspects of the use of training services by SMEs are different in all size classes.

The research method applied is quantitative research carried out among companies from the SME sector in the Pomeranian region of Poland.

\section{Theoretical framework}

Importance of knowledge and knowledge management for SMEs

Knowledge is becoming more and more important in the face of knowledge-based economy development (e.g. Zieba, 2008). Knowledge productivity, which is expressed by the ability to collect information, create new knowledge, disseminate and apply this knowledge for the development and introduction of innovations, is a key economic factor in this new knowledge-based economy (Kessels, 2001). This fact does not only concern large companies, which by definition have at their disposal greater financial and human resources to gain and produce knowledge, but also SMEs, 
which often have scarce resources and cannot afford managing their knowledge in a complex manner. At the same time, as the research confirms, SMEs may benefit from knowledge management initiatives tremendously (e.g. Wickert and Herschel, 2001; Edvardsson, 2006).

SMEs may manage their knowledge in various ways. Among knowledge management (KM) practices in SMEs one may find:

- $\quad$ training and mentoring employees;

- $\quad$ policies and strategies of KM;

- $\quad$ knowledge capturing and acquisitions from the outside;

- $\quad$ effect of organizational culture (Bozbura, 2007).

As one can notice, training and mentoring employees is among those KM practices that can be applied in small and medium enterprises. Also Wickert and Herschel (2001) proposed training among a number of techniques that enable smaller companies to acquire and retain knowledge. As SMEs often cannot afford to hire high-class specialist in a certain field and they often face problems with acquiring appropriate skills (Robertson, 2003), one way to obtain the necessary knowledge by available employees is to send them for appropriate training. This option is not free of disadvantages, e.g. the risk of losing trained employees in due course (Devins, Johnson and Sutherland, 2004; Mako, 2005) or costs of training, but it offers the possibility to fill the knowledge and competences gap in a short period of time. In the next section the importance of skills development for SMEs functioning is described.

\section{Skills development in knowledge-based economy}

With a rising importance of knowledge for SMEs functioning, described in the previous sections, skills development of employees is becoming more and more significant. The pace of changes in the environment is very high. Technologies and products are becoming obsolete much sooner after being produced than it was the case ten or twenty years ago. What is more, changes and innovations concern not only technological factors, but they often constitute a complex social process with human factors playing a very significant role (Adomaviciute, Janiunaite and Stuopyte, 2012). Therefore, as McCole et al. (2001) state: 'the nature and quality of employee skills and competencies can facilitate or hinder the positioning of a company's distinctive or differentiated competitive characteristics in a world where the relative standard of goods and services has become similar and easy to imitate, (McCole et al., 2001). This quotation highlights the importance of skills and competencies of employees, which is becoming a source of competitive advantage not only for large companies, but also for SMEs. In general, it can be said that human capital is often considered as one of the most crucial assets in companies, as it helps in generating creativity and innovations (Bozbura, 2007).

One the basis of the above one may conclude that companies need to invest in skills development of their employees, as it allows them to be competitive on the market in the knowledge based economy. Moreover, skills development also results in higher productivity, i.e. when people gain new skills, they are can produce more in a given time, with a certain effort (Lange et al., 2000). This further contributes to better profitability (O'Regan, Stainer and Sims, 2010).

\section{Training services for SMEs}

There are many reasons for paying closer attention to organizational training. Among them are those mentioned by O'Regan, Stainer and Sims (2010), i.e.: assisting communication, positively motivating and playing a significant role to train dormant skills of employees. The value of training may also originate from the fact that it allows to turn knowledge info effective and efficient operations.

As stated in the previous sections, skills and competencies development is a crucial issue also for SMEs. Therefore, SMEs should pay closer attention to training possibilities due to several factors:

a) they often lack skilled employees - in many cases they lose the struggle for talents with larger entities offering higher wages and additional, non-financial profits;

b) they miss development opportunities (e.g. entering new markets) due to lack of skills and competences;

c) they lose competitive advantage due to lack of appropriate knowledge and skills.

Additionally, as Saa-Perez, Diaz-Diaz and BallesterosRodriguez (2012) found out in their research: 'training has a high moderating role in the relationship between the knowledge assets that the firm has and its ability to generate new products'. It means that training might help SMEs in creating new products by integrating knowledge resources the company has. Ibrahim and Ellis (2003) suggested even that training could improve the survival rate of small companies.

Despite professed reasons for training SMEs employees, still not so many firms from this sector provide their employees with training. For example, Westhead and Storey (1996) indicate that SMEs employees more rarely receive training than their larger counterparts. The same trend is confirmed in other research, according to which companies from SME sector do not seem to invest much in employee training and often perceive training as a cost rather than an investment (McCole et al., 2001). Generally, it is reported in the literature that training needs increase with the company size - the bigger the company, the bigger the demand for training. Smaller companies more rarely decide on training services, although they might benefit more than large firms after receiving the training with regard to company performance, technology transfer and productivity (Hashim and Wok, 2013).

Reluctance of SMEs owners/managers to use training services results from various factors. Johnston and Loader (2003) list the following reasons for limited usage of training services by SMEs:

- their owner/managers are often unconvinced of the value of training;

- they are responsive and ad hoc in their training choices;

- they are unaware of available training;

- sufficient understanding of SMEs by training providers requires close relationships between 
providers and SMEs - it may result in high costs of trainings;

- they require easy access in terms of time, location and no disruption to work.

- they prefer informality in training and learning (Johnston and Loader, 2003).

Other research reports additional reasons, like: inability to acknowledge the need for training (Sargeant, 1996), lack of available employee time (Kerr and McDougall (1999), preference to informal training (Anderson et al., 2001), reluctance to invest in people (Panagiotakopoulos, 2011). Moreover, employee training in SMEs is often informal, unplanned, reactive and shortterm oriented (Hill and Stewart, 2000), which results in lack of official statistics on this type of training.

Large companies usually have systematic approach to training, i.e. they have special units responsible for training and development dedicated to training needs of their employees. They also regularly carry out the examinations on research needs of their employees. Not many SMEs apply such a solution (Kotey and Folker, 2007), so they need to search for training options and providers outside the company, on the market.

As there are usually a great variety of training services providers, SMEs need to assume some kind of selection criteria, if they want to choose wisely and with greatest benefits. Here the question appears. What are or should be the factors determining the selection and usage of training services among SMEs.

The first crucial thing is to determine precisely the need for training and skills improvement (Chi, Wu and Lin, 2008; Roy, 2009). It is important to remember that from the point of view of an SME, skills and competencies development is justified only if it helps in sustaining competitive advantage. According to Wickert and Herschel (2001), 'the key objective in training for smaller firms should always be to have a firm grip on what key knowledge is needed to stay or become competitive and to establish who should receive what kind of training in order to meet these future requirements'. Kailer and Scheff (1999) indicate some quality criteria for training and education services - according to them these are the practicability of the products and the identification of training needs. In the research carried out by those two authors, examined SMEs indicated the following selection criteria for external know-how providers ${ }^{1}$ : good pricevalue relationship (64 percent), branch/technical knowledge of the provider (62,4 percent), good experience so far (50 percent) (Kailer and Scheff, 1999). Here another question appears. What are the selection criteria for choosing particular training and training provider by SMEs? In the following section, research hypotheses based on the above theoretical framework will be formulated.

\section{Hypotheses}

After having examined the theoretical framework, we hypothesise that:

\footnotetext{
${ }^{1}$ External know-how providers are according to Kailer and Scheff (1999) training, consulting and research institutions.
}

H1: Probability of using training services increases alongside with the size of firms.

The data gathered in our research allow us to split this hypothesis into two sub-hypotheses:

Hla: Bigger firms more often declare they have used training services in the past.

H1b: Bigger firms more often declare their intention to use training services in the future.

We expect that bigger businesses are not only less financially constrained, but their scope of operation is wider. Therefore, their demand for training services should be bigger with regard to all examined types of training services. As a result we propose:

H2: Bigger businesses more often signal demand for major types of training services.

Even though we hypothesise that bigger businesses are generally more involved in training services, it seems logical to assume that the needs for different types of training services, the rationale behind those needs and the determinants of service provider selection should vary across size classes of examined business. If that is the case, the priorities in demand, reasons and determinants - defined as the most often selected answers - should be different among micro-, small and medium sized businesses. Hence:

H3: Priorities given to various aspects of the use of training services by SMEs are different in all size classes.

The above hypothesis can be split into three, individually embracing all the examined aspects:

H3a: Priorities in demand for training services vary across size classes of businesses.

H3b: Priorities in reasons for using training services vary across size classes of businesses.

H3c: Priorities in determinants of service provider selection vary across size classes of businesses.

\section{Research methodology}

Data on using training service in SMEs were collected in 2009 within the $3^{\text {rd }}$ edition of Pomeranian Economic Observatory (PEO). PEO is a panel data study having been conducted in Poland since 2006. The research sample consisted of 949 firms examined with the use of a questionnaire. Firm size composition of the sample is shown in Figure 1.

Size classification of firms was based on the number of full time employees, with microfirms having up to nine employees, small firms having from 10 to 49 employees and medium-sized firms employing from 50 up to 249 individuals.

In the research sample microfirms are clearly underrepresented in comparison with the general population in the SME sector, which results from methodological assumptions of PEO. PEO is primarily focused on researching small and medium sized businesses only. In the initial PEO sample 43 firms out of 2132 examined eventually turned out to be microfirms, as they actually employed less than 10 people. Due to employment changes between 2006 and 2009, when our study was conducted, the number of microfirms increased to 154. The scope of our research remains different from the scope of PEO, therefore 


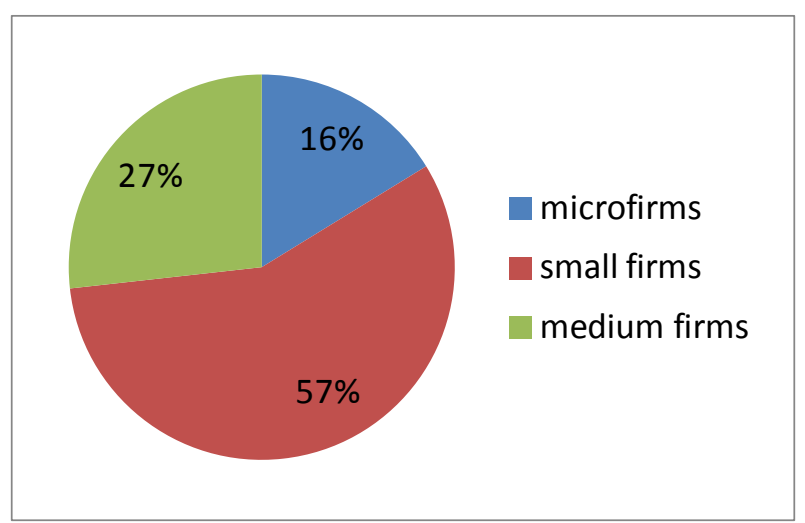

Figure 1. Examined firms by size

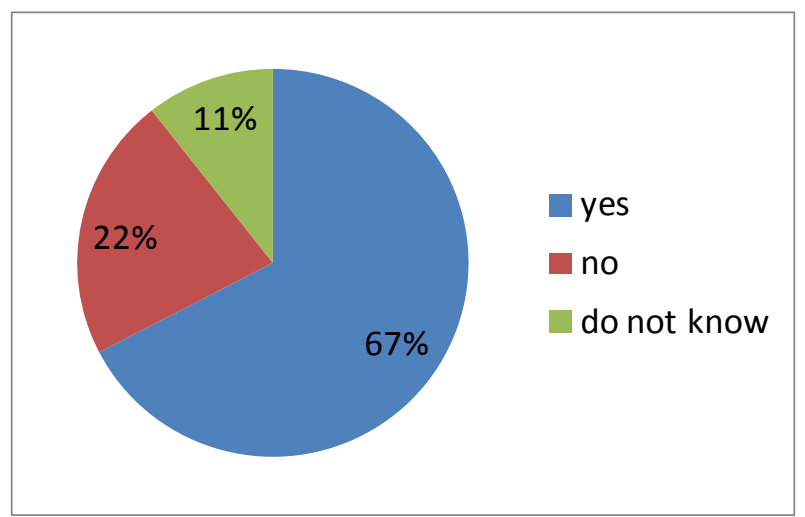

Figure 2. Intention to use training services in the future

we decided to use the data on microfirms in spite of their underrepresentation in the sample. This characteristics of our sample does not influence the possibilities for testing hypotheses, but it certainly has some impact on the overall results obtained in the research.

73 percent of the examined firms declared that they had used training services offered by other companies. As can be seen in Figure 2, the majority of firms intend to use those service also in the future. Those intentions are especially present among firms that have already used training services in the past: nine out of ten declare they would continue this practice. That indicates high level of satisfaction gained from training services. Another explanation could be the fact that some firms must use training services as a result of legal requirements imposed on them. Figure 4 shows, however, that this applies only to 25 percent of the sample.

Examined firms declared the biggest demand for training services in three areas: production technology, accounting and finance, and marketing and sales. Other types of training are more rarely perceived as needed and important. Complete data on demand for various training services is presented in Figure 3.

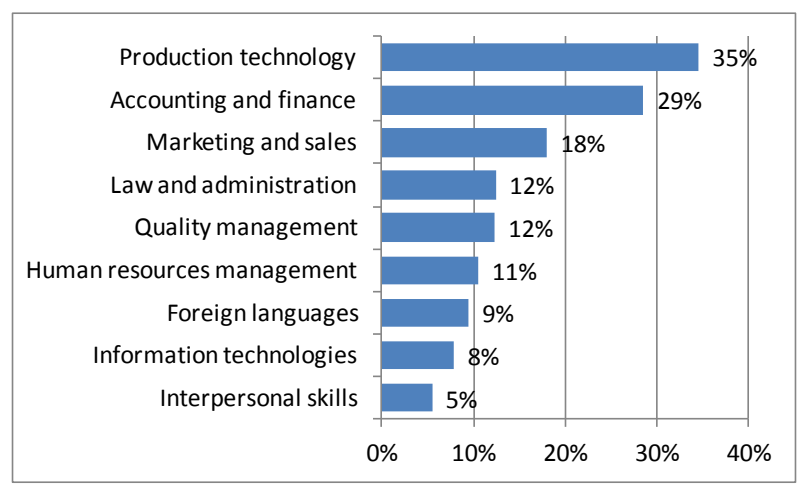

Figure 3. Demand for training services with regard to subject 


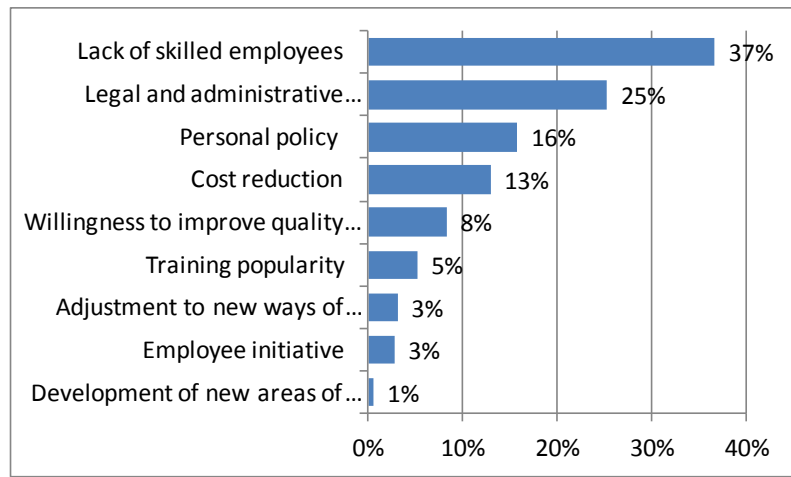

Figure 4. Reasons for using training services

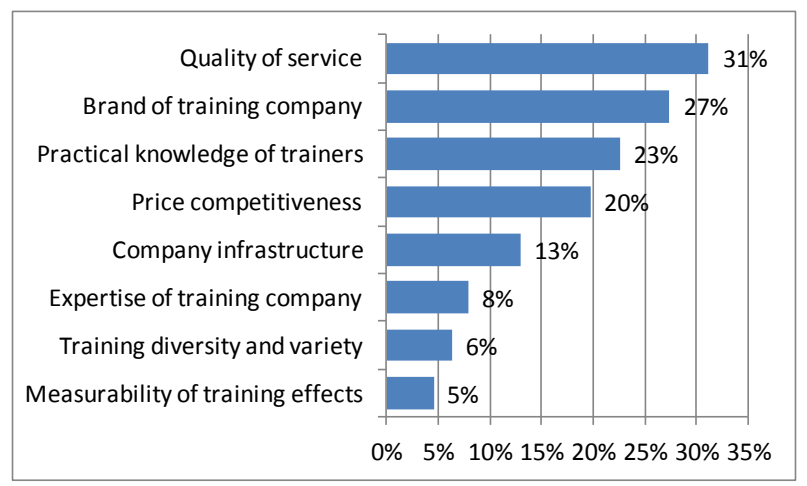

Figure 5. Determinants of training provider selection

Push factors dominate as the determinants of using training services in our sample. Examined SMEs use training services mostly because they have to and not because they want to; 37 percent of them are pushed to use training services, as their employees lack skills that are needed. One in every four firms needs training services in order to comply with legal requirements. Positive reasons (pull factors) for using training services are rather rarely mentioned (Figure 4).

Not surprisingly, quality of service appears as the most important determinant in the process of selecting training companies (Figure 5). In many cases it may be difficult to assess the quality of training services beforehand. This is probably why 27 percent indicated brand of the training company as important factor in choosing training provider. Firms can treat brand of provider as a proxy for quality of services it offers. This line of reasoning is confirmed by the fact that merely 5 percent of examined firms indicated 'measurability of training effects; as important. Objectively, this is certainly important, but our respondents apparently realize that effects of training are often difficult to measure.

Only 20 percent of firms from our sample consider competitiveness of price as an important determinant of selection.

Taking into account that SMEs are very often financially constrained, this is an interesting finding. It suggests that even in case of firms using training services just to comply with legal requirements, the quality of service is still important and therefore prices - usually negatively related to quality - are not a critical factor in the process of selecting a training company.

\section{Use of training services in the past}

\begin{tabular}{|c|c|c|c|c|c|c|}
\hline & \multicolumn{2}{|c|}{ Microfirms } & \multicolumn{2}{|c|}{ Small firms } & \multicolumn{2}{|c|}{ Medium firms } \\
\hline & $\mathbf{n}$ & $\%$ & $\mathbf{n}$ & $\%$ & $\mathbf{n}$ & $\%$ \\
\hline Yes & 80 & 51.95 & 399 & 73.75 & 212 & 83.46 \\
\hline No & 74 & 48.05 & 140 & 25.88 & 42 & 16.54 \\
\hline No answer & 0 & 0.00 & 2 & 0.37 & 0 & 0.00 \\
\hline p-value ${ }^{2}$ : & \multicolumn{6}{|c|}{$2.3 \mathrm{E}-11$} \\
\hline
\end{tabular}

\footnotetext{
${ }^{2} \chi^{2}$ test was applied only to 'yes' and 'no' answer distribution.
} 
Intention to use training services in the future

\begin{tabular}{|l|r|r|r|r|r|r|}
\cline { 2 - 7 } \multicolumn{1}{c|}{} & \multicolumn{1}{c|}{ Microfirms } & \multicolumn{2}{c|}{ Small firms } & \multicolumn{2}{c|}{ Medium firms } \\
\cline { 2 - 7 } \multicolumn{1}{c|}{} & \multicolumn{1}{c|}{$\mathbf{n}$} & \multicolumn{1}{c|}{ n } & \multicolumn{1}{c|}{$\%$} & \multicolumn{1}{c|}{ n } & \multicolumn{1}{c|}{$\%$} \\
\hline Yes & 73 & 47.40 & 369 & 68.21 & 197 & 77.56 \\
\hline No & 60 & 38.96 & 114 & 21.07 & 34 & 13.38 \\
\hline Do not know & 21 & 13.64 & 57 & 10.54 & 23 & 9.06 \\
\hline No answer & 0 & 0.00 & 1 & 0.18 & 0 & 0.00 \\
\hline \multicolumn{3}{|c}{ p-value $^{3}:$} & \multicolumn{3}{|c}{$6,5 \mathrm{E}-09$} \\
\hline
\end{tabular}

Table 3

Demand for training services

\begin{tabular}{|c|c|c|c|c|c|c|c|}
\hline & \multicolumn{2}{|c|}{ Microfirms } & \multicolumn{2}{|c|}{ Small firms } & \multicolumn{2}{|c|}{ Medium firms } & \multirow[t]{2}{*}{ p-value } \\
\hline & n & $\%$ & $\mathbf{n}$ & $\%$ & $\mathbf{n}$ & $\%$ & \\
\hline 1. Accounting and finance & 23 & 14.94 & 144 & 26.62 & 104 & 40.94 & 0.000 \\
\hline 2. Law and administration & 11 & 7.14 & 64 & 11.83 & 43 & 16.93 & 0.012 \\
\hline 3. Human resources management & 10 & 6.49 & 56 & 10.35 & 34 & 13.39 & 0.087 \\
\hline 4. Interpersonal skills & 4 & 2.60 & 33 & 6.10 & 15 & 5.91 & 0.228 \\
\hline 5. Foreign languages & 10 & 6.49 & 50 & 9.24 & 30 & 11.81 & 0.198 \\
\hline 6. Marketing and sales & 24 & 15.58 & 88 & 16.27 & 59 & 23.23 & 0.041 \\
\hline 7. Production technology & 36 & 23.38 & 186 & 34.38 & 106 & 41.73 & 0.000 \\
\hline 8. Quality management & 8 & 5.19 & 60 & 11.09 & 49 & 19.29 & 0.000 \\
\hline 9. Information technologies & 12 & 7.79 & 36 & 6.65 & 27 & 10.63 & 0.152 \\
\hline
\end{tabular}

Table 4

Ranking of training services demanded

\begin{tabular}{|l|c|c|c|c|c|c|c|c|c|}
\hline \multirow{2}{*}{ Class size: } & \multicolumn{9}{|c|}{ Training services ranking: } \\
\cline { 2 - 10 } & $\mathbf{1}$ & $\mathbf{2}$ & $\mathbf{3}$ & $\mathbf{4}$ & $\mathbf{5}$ & $\mathbf{6}$ & $\mathbf{7}$ & $\mathbf{8}$ & $\mathbf{9}$ \\
\hline Microfirms & 7 & 6 & 1 & 9 & 2 & 3 & 5 & 8 & 4 \\
\hline Small firms & 7 & 1 & 6 & 2 & 8 & 3 & 5 & 9 & 4 \\
\hline Medium firms & 7 & 1 & 6 & 8 & 2 & 3 & 5 & 9 & 4 \\
\hline
\end{tabular}

Reasons for using training services

\begin{tabular}{|c|c|c|c|c|c|c|c|}
\hline & \multicolumn{2}{|c|}{ Microfirms } & \multicolumn{2}{|c|}{ Small firms } & \multicolumn{2}{|c|}{ Medium firms } & \multirow{2}{*}{ p-value } \\
\hline & $\mathbf{n}$ & $\%$ & $\mathbf{n}$ & $\%$ & n & $\%$ & \\
\hline 1. Cost reduction & 19 & 12.34 & 67 & 12.38 & 37 & 14.57 & 0.673 \\
\hline 2. Personal policy & 18 & 11.69 & 82 & 15.16 & 50 & 19.69 & 0.082 \\
\hline 3. Legal and administrative requirements & 21 & 13.64 & 130 & 24.03 & 89 & 35.04 & 0.000 \\
\hline 4. Adjustment to new ways of working & 0 & 0.00 & 18 & 3.33 & 9 & 3.54 & 0.067 \\
\hline 5. Lack of skilled employees & 34 & 22.08 & 202 & 37.34 & 112 & 44.09 & 0.000 \\
\hline 6. Willingness to improve quality offered & 8 & 5.19 & 43 & 7.95 & 28 & 11.02 & 0.105 \\
\hline 7. Development of new areas of activity & 0 & 0.00 & 3 & 0.55 & 3 & 1.18 & 0.324 \\
\hline
\end{tabular}

\footnotetext{
${ }^{3} \chi^{2}$ test was applied only to 'yes', 'no' and 'do not know' answer distribution.
} 


\section{Results}

We hypothesised that bigger firms use training services more often than their smaller counterparts. This hypothesis (H1) was split into two - H1a and H1b. The former suggested bigger firms should have greater experience in using training services in the past. The results clearly support our expectations. Using training services is generally quite popular - even among microfirms, but the share of training services users evidently increases alongside with size of firms (Table 1).

Hypothesis $\mathrm{H} 1 \mathrm{~b}$ refers to intentions of using such services in the future and it is undoubtedly confirmed by the data in Table 2. In all categories (micro, small and medium) the share of those intending to use training services in the future is slightly lower than in case of using them in the past. Nevertheless, the pattern is repeated here: bigger firms more often declare the intention to use training eservices than their smaller counterparts.

As both H1a and H1b are confirmed in a statistically significant way, we consider that our data fully support hypothesis $\mathrm{H} 1$.

Data gathered in Table 3 presents nine major types of training services and the demand for the reported by firms from different size classes. There are considerable differences in demand for particular types of services, with some being very popular (e.g. production technology) and some not (interpersonal skills). Differences appear also between size classes of firms. As hypothesized in $\mathrm{H} 2$, we expected that bigger firms would declare their demand for particular types of training services more often than their smaller counterparts. Data collected and $\chi^{2}$ test results ${ }^{4}$ seem to support this view.

In case of three out of nine types of training services (accounting and finance, production technology, quality management) we obtained a very strong statistical support with p-value below 0.001 . For 'accounting and finance' the greater demand from bigger firms results most likely from two following facts: 1 . Unlike their smaller counterparts, they avoid outsourcing of accounting services to external firms. 2. Accountancy in bigger firms is usually more complicated, because they have operated as joint stock companies or limited companies and not as sole proprietorship. Training services with regard to 'production technology' are more popular among bigger firms certainly because of differences in the scope of business operations. Firms from production industries are usually bigger than firms from services industries. As a consequence bigger firms may need training on production technology more often, because they are actually more often involved in production. In bigger firms the whole production process may also be more complex and therefore demand for additional skills and competencies of employees may be higher. This reasoning is in line with the explanation for the last type of training service - quality management. If the production process in more complex in bigger firms, then this increased complexity combined with higher number of employees and more complicated structure of firm makes quality management more difficult. In such case quality

\footnotetext{
${ }^{4}$ The test was applied to 'yes' and 'no' answer distribution, but for greater clarity in the table we show only positive answers.
}

management cannot be performed by some routine activities of owner/manager, as it often takes place, especially in microfirms.

There are also significant differences between size classes with regard to training services on 'law and administration' and 'marketing and sales'. P-value for those two categories was below the conventional level of 0.05 . A weak support (p-value below 0.1) was obtained for differences regarding 'human resources management'. We believe that those differences can be easily explained by the character of small (and especially micro-) firms. They rarely employ specialists to solve legal problems (lawyers or counsellors). When they need legal advice they just acquire it from external experts. For typical 'mom-and-pop' firms the scale of business operations does not require and does not allow using sophisticated marketing tools and techniques. But for bigger (medium) firms the picture is different. They are more likely to have legal specialists. Marketing tools, marketing and sales techniques are more adequate for them and more needed.

We could not identify any statistically significant differences for the remaining three types of training services, but all in all it should be noted that hypothesis $\mathrm{H} 2$ is quite well supported by our data.

According to H3a hypothesis, priorities in demand for training services should vary across size classes of firms. In other words, smaller and bigger firms should perceive different types of training services as the most necessary and useful. Surprisingly, the data provided in Table 3 does not support this expectation. Regardless of the size class, top three training services needed by the examined firms are 'production technologies' (undoubtedly number one across all classes), 'accounting and finance', and 'marketing and sales'. The least necessary training services are in fact: 'foreign languages', 'information technologies' and 'interpersonal skills'. The ranking of what training services are needed is very similar for all three size classes, as can be seen in Table 4. Numbers describing particular training services are ordinal numbers from Table 3 ('accounting and finance' being 1 and 'information technologies' being 9).

The only important differences between size classes apply to 'information technologies', which are ranked high ( $4^{\text {th }}$ position) by microfirms and very low by others $\left(8^{\text {th }}\right.$ position) and 'quality management' - quite needed by small and medium sized businesses $\left(4^{\text {th }}-5^{\text {th }}\right.$ position) and rather unnecessary for microfirms ( $8^{\text {th }}$ position).

When it comes to reasons for using training services, differences across size classes appear in two cases: legal and administrative requirements and lack of skilled employees (Table 5). This is not surprising. We have already indicated that bigger firms in Poland are more exposed to formal requirements and regulations because of their organizational form. Smaller firms, operating as sole proprietorship, find many of those requirements and regulations not applicable. Lack of skilled employees is the reason for using training services twice as often among medium firms as among microfirms. It is certainly not because microfirms have more skilled employees, but because they do not need skilled employees to the extent that their bigger counterparts need them. 
Ranking of reasons for using training services

\begin{tabular}{|l|c|c|c|c|c|c|c|}
\hline \multirow{2}{*}{ Class size: } & \multicolumn{7}{|c|}{ Ranking of reasons: } \\
\cline { 2 - 8 } & $\mathbf{1}$ & $\mathbf{2}$ & $\mathbf{3}$ & $\mathbf{4}$ & $\mathbf{5}$ & $\mathbf{6}$ & $\mathbf{7}$ \\
\hline Microfirms & 5 & 3 & 1 & 2 & 6 & 4 & 7 \\
\hline Small firms & 5 & 3 & 2 & 1 & 6 & 4 & 7 \\
\hline Medium firms & 5 & 3 & 2 & 1 & 6 & 4 & 7 \\
\hline
\end{tabular}

Table 7

Determinants of training provider selection

\begin{tabular}{|c|c|c|c|c|c|c|c|}
\hline & \multicolumn{2}{|c|}{ Microfirms } & \multicolumn{2}{|c|}{ Small firms } & \multicolumn{2}{|c|}{ Medium firms } & \multirow{2}{*}{ p-value } \\
\hline & $\mathbf{n}$ & $\%$ & $\mathbf{n}$ & $\%$ & $\mathbf{n}$ & $\%$ & \\
\hline 1. Quality of service & 42 & 27.27 & 170 & 31.42 & 84 & 33.07 & 0.465 \\
\hline 2. Price competitiveness & 18 & 11.69 & 98 & 18.11 & 71 & 27.95 & 0.000 \\
\hline 3. Practical knowledge of trainers & 22 & 14.29 & 118 & 21.81 & 74 & 29.13 & 0.002 \\
\hline 4. Training diversity and variety & 2 & 1.30 & 42 & 7.76 & 16 & 6.30 & 0.015 \\
\hline 5. Brand of training company & 31 & 20.13 & 154 & 28.47 & 75 & 29.53 & 0.083 \\
\hline 6. Company infrastructure & 16 & 10.39 & 68 & 12.57 & 39 & 15.35 & 0.322 \\
\hline 7. Measurability of training effects & 6 & 3.90 & 22 & 4.07 & 15 & 5.91 & 0.467 \\
\hline 8. Expertise of training company & 10 & 6.49 & 49 & 9.06 & 16 & 6.30 & 0.315 \\
\hline
\end{tabular}

Table 8

\section{Ranking of determinants of training provider selection}

\begin{tabular}{|l|c|c|c|c|c|c|c|c|}
\hline \multirow{2}{*}{ Class size: } & \multicolumn{9}{|c|}{ Training services ranking: } \\
\cline { 2 - 9 } & $\mathbf{1}$ & $\mathbf{2}$ & $\mathbf{3}$ & $\mathbf{4}$ & $\mathbf{5}$ & $\mathbf{6}$ & $\mathbf{7}$ & $\mathbf{8}$ \\
\hline Microfirms & 1 & 5 & 3 & 2 & 6 & 8 & 7 & 4 \\
\hline Small firms & 1 & 5 & 3 & 2 & 6 & 8 & 4 & 7 \\
\hline Medium firms & 1 & 5 & 3 & 2 & 6 & 8 & 4 & 7 \\
\hline
\end{tabular}

Contrary to hypothesis $\mathrm{H} 3 \mathrm{~b}$, there are no differences in priorities given to reasons for using training services. The ranking of those reasons is presented in Table 6 and reveals no differences in this regard across all three size classes. Examined firms use training services for similar reasons, mostly because they have to (lack of skilled employees and legal and administrative requirements) and rarely because they want to. Innovative motives for using training services (adjustment to new ways of working and development of new areas of activity) are invariably ranked as the least important reasons in all size classes.

Training services are widely available on the Polish market. Many business entities provide them on large scale, some of them with the help of EU funding. That poses the question about selection criteria that firms use to choose the right training services provider. First of all it should be stated here that bigger firms take into account more determinants than their smaller counterparts. That is very evident in case of price competitiveness and practical knowledge of trainers (Table 7).

The ranking of priorities given to particular determinants of training provider selection is virtually the same in all size classes (Table 8). The results are not only very similar among bigger and smaller firms, but also quite consistent internally. They show that the most important determinant is quality expressed either directly (by choosing option 1 in Table 6) or indirectly (option 5 and 3 in Table 7). Quality is then followed by price competitiveness.

This finding that quality is apparently more important selection determinant than price is quite surprising when taking into account the general motivation for using training services. Examined firms use them mostly because of push factors. One of the most important factors is the need to comply with legal and administrative requirements. In order to just comply one does not need high quality and since compliance is associated with costs (the price paid to training services provider), it would be natural that firms may neglect quality to be more cost-effective. But this is not the case in the light of our research. Even if pushed to use training services, firms want to get as much value from them as possible.

\section{Conclusions}

Skills and competencies development is certainly becoming one of the main factors in company's struggle for competitive advantage on the market. This is why companies also from the SME sector should pay more attention to training and development of employees' skills.

On the basis of the data analysed in this article, some conclusions concerning the usage of training services by Pomeranian companies can be drawn. 
First of all, most of the analysed companies declared the intention to use training services in the future. It means that training services are not that uncommon among companies from SME sector. That is a positive observation. Moreover, the probability of using training services is positively correlated with the size of firm - bigger firms more often declare they have used training services in the past and they are more often willing to use them in the future. The broader scope of business operations typical of bigger firms is associated with broader demand for training services. It means that bigger firms not only use training services more often, but they also use a greater variety of them.

Secondly, when SMEs decide on using training services, they do that more often due to push factors, like lack of employee skills, than pull factors, e.g. employee initiative. Also, in the process of training selection, SMEs decide on the basis of quality of service and brand of training company. Keeping in mind that SMEs are often financially constrained, that is an interesting finding.

Thirdly, priorities given to various aspects of the use of training services among particular firm classes appear to be the same. The authors were unable to discover any significant differences with regard to all three analysed aspects.

This topic could be further explored in other regions of Poland, as well as in other countries to compare the results and draw more universal conclusions on these issues.

\section{References}

1. Adomaviciute, E., Janiunaite, B., \& Stuopyte, E. (2012). The Profile of Social Entrepreneurs Working for Non-Governmental Organizations. Social Sciences, 77, (3), 17-29.

2. Al-Madhoun, M. I., \& Analoui, F. (2003). Managerial skills and SMEs' development in Palestine. Career Development $\begin{array}{llll}\text { International, } & 8, & \text { (7), }\end{array}$ http://dx.doi.org/10.1108/13620430310505322

3. Bozbura, F. T. (2007). Knowledge management practices in Turkish SMEs. Journal of Enterprise Information Management, 20, (2), 209-221. http://dx.doi.org/10.1108/17410390710725788

4. Chi, N.-W., Wu, C.-Y., \& Lin, C. Y.-Y. (2008). Does training facilitate SME's performance? The International Journal of Human Resource Management, 19, (10), 1962-1975. http://dx.doi.org/10.1080/09585190802324346

5. Devins, D., Johnson, S., \& Sutherland, J. (2004). Different skills and their different effects on personal development: An investigation of European Social Fund Objective 4 financed training in SMEs in Britain. Journal of European Industrial $\begin{array}{lll}\text { Training, } & 28, & \text { (1), }\end{array}$ http://dx.doi.org/10.1108/03090590410513910

6. Dominiak, P., Wasilczuk, J., Daszkiewicz N., Zięba, K., \& Sobiechowska-Ziegert, A. (2010). Report 2010. Small and medium enterprises sector in Pomerania in worsened economic conditions. Pomerania Development Agency C.O., Gdansk.

7. Edvardsson, I. R. (2006). Knowledge management in SMEs: the case of Icelandic firms. Knowledge Management Research \& $\begin{array}{lllr}\text { Practice, } & 4 & \text { (4), 275-282. }\end{array}$ http://dx.doi.org/10.1057/palgrave.kmrp.8500111

8. Fong, C.-Y., Ooi, K.-B., Tan, B.-I., Lee, V.-H., \& Chong, A. Y.-L. (2011). HRM practices and knowledge sharing: an empirical study. International Journal of Manpower, 32, (5/6), 704-723. http://dx.doi.org/10.1108/01437721111158288

9. Gray, C. (2006). Absorptive capacity, knowledge management and innovation in entrepreneurial small firms. International Journal of Entrepreneurial Behaviour \& Research, 12, (6), 345-360. http://dx.doi.org/10.1108/13552550610710144

10. Hashim, J., \& Wok, S. (2013). Who benefits from training: big guy or small fry? Development and Learning in Organizations, 27, (3), 14-17. http://dx.doi.org/10.1108/14777281311315856
11. Heneman, R. L., Tansky, J. W., \& Camp, S. M. (2000). Human resource management practices in small and medium-sized enterprises: unanswered questions and future research perspectives, Entrepreneurship: Theory \& Practice, 25, (1), 11-26.

12. Hill, R., \& Stewart, J. (2000). Human resource development in small organizations. Journal of European Industrial Training, 24, (2/3/4), 105-117. http://dx.doi.org/10.1108/03090590010321070

13. Huang, T.-C. (2001). The relation of training practices and organizational performance in small and medium size enterprises. Education + Training, 43, (8/9), 437-444. http://dx.doi.org/10.1108/00400910110411620

14. Ibrahim, A. B., \& W. Ellis (2003). Family Business Management, Concepts and Practices. Dubuque, IA: Kendall/Hunt.

15. Johnston, K., \& Loader, K. (2003). Encouraging SME participation in training: identifying practical approaches. Journal of European Industrial Training, 27, (6), 273-280. http://dx.doi.org/10.1108/03090590310479901

16. Jones, J. T. (2005). The determinants of training in Australian manufacturing SMEs. Education + Training, 47, (8/9), 605-615. http://dx.doi.org/10.1108/00400910510633143

17. Kailer, N., \& Scheff, J. (1999). Knowledge management as a service: co-operation between small and medium-sized enterprises (SMEs) and training, consulting and research institutions. Journal of European Industrial Training, 23, (7), 319-328. http://dx.doi.org/10.1108/03090599910287332

18. Kessels, J. W. M. (2001). Learning in organizations: a corporate curriculum for the knowledge economy. Futures, 33, 497-506. http://dx.doi.org/10.1016/S0016-3287(00)00093-8

19. Kotey, B., \& Folker C. (2007). Employee Training in SMEs: Effect of Size and Firm Type-Family and Nonfamily. Journal of Small Business Management, 45, (2), 214-238.

20. Kyriakidou, O., \& Maroudas, L. (2010). Training and development in British hospitality, tourism and leisure SMEs. Managing Leisure, $15, \quad(1-2), \quad 32-47$. http://dx.doi.org/10.1080/13606710903447998

21. Lange, T., Ottens M., \& Taylor, A. (2000). SMEs and barriers to skills development: a Scottish perspective. Journal of European Industrial Training, 24, (1), 5-11. http://dx.doi.org/10.1108/03090590010308219

22. Lyons, P., \& Mattare, M. (2011). How can very small SMEs make the time for training and development: skill charting as an example of taking a scenistic approach. Development and Learning in Organizations, 25, (4), 15-19. http://dx.doi.org/10.1108/14777281111147053

23. Makó, C. (2005). Training and competence development in the SME sector: the Hungarian Case. Journal for East European Management Studies, 156-185.

24. McCole, P., Morrow, T., Ponsonby, S., \& Kelly, B. (2001). The potential training impact of technology on SMEs in Northern Ireland. Journal of European Industrial Training, 25, (2/3/4), 9097. http://dx.doi.org/10.1108/EUM0000000005440

25. O'Regan, N., Stainer, L., \& Sims, M. (2010). Training in SMEs and its relationship to profitability. International Journal of Human Resources Development and Management, 10, (2), 166-181. http://dx.doi.org/10.1504/IJHRDM.2010.031442

26. Panagiotakopoulos, A. (2011). Barriers to employee training and learning in small and medium-sized enterprises (SMEs). Development and Learning in Organizations, 25, (3), 15-18. http://dx.doi.org/10.1108/14777281111125354

27. Reid, R. S., \& Harris, R. I. (2002). The determinants of training in SMEs in Northern Ireland. Education + Training, 44, (8/9), 443450. http://dx.doi.org/10.1108/00400910210449286

28. Robertson, P. L. (2003). The role of training and skilled labour in the success of SMEs in developing economies. Education + Training, 45, (8/9), 461-473. http://dx.doi.org/10.1108/00400910310508856

29. Roy, A. (2009). The Training Process of SMEs: What Motivates SMEs to Use E-Learning. International Journal of Advanced Corporate Learning (iJAC), 2, http://dx.doi.org/10.3991/ijac.v2i3.991

30. Saá-Pérez, P. D., Díaz-Díaz, N. L., \& Ballesteros-Rodríguez, J. L. (2012). The role of training to innovate in SMEs. Innovation: Management, Policy \& Practice, 14, (2), 218-230. http://dx.doi.org/10.5172/impp.2012.14.2.218

31. Westhead, P., \& Storey, D. (1996). Management training and small firm performance: why is the link so weak? International Small 

Business
Journal,
14 , http://dx.doi.org/10.1177/0266242696144001

32. Wickert, A., \& Herschel, R. (2001). Knowledge- management issues for smaller businesses. Journal of Knowledge Management, 5, (4), 329-337. http://dx.doi.org/10.1108/13673270110411751

33. Zieba, M. (2008). The influence of a knowledge-based economy on the functioning of contemporary organization. Foundations of Control and Management Sciences, 10, 94-10.

34. Żołnierski, A. (2009). Znaczenie sektora MSP w Polsce, in: Raport $o$ stanie sektora malych $i$ średnich przedsiębiorstw $w$ Polsce $w$ latach 2007-2008. Polska Agencja Rozwoju Przedsiębiorczości.

\section{K. Zieba, M. Zieba}

Mokymo paslaugos smulkaus ir vidutinio verslo įmonėse: įžvalgos iš Lenkijos

\section{Santrauka}

Smulkaus ir vidutinio verslo ịmonès tampa vis svarbesnès Europos ir pasaulinėse ekonomikose (pvz., Reid ir Harris, 2002; Robertson, 2003; AlMadhoun ir Analoui, 2003; Kyriakidou ir Maroudas, 2010). Pavyzdžiui, Jungtinèje Karalysteje tokio tipo įmonès sudaro $90 \%$ viso verslo sektoriaus ir jose iddarbinta beveik $50 \%$ darbo jègos (Gray, 2006). Smulkaus ir vidutinio verslo įmonių sektorius taip pat ženkliai prisideda ir prie Lenkijos ekonomikos sėkmès (Żołnierski, 2009). Šiuo metu smulkaus ir vidutinio verslo įmonès išsivysčiusiose ekonomikose sudaro pagrindinę rinkos dalị ir ịdarbina didžiają darbo jègos dali, todèl vis didèja mokslininku dèmesys tokio tipo ịmonių funkcionavimui bei jų sẻkmès ,receptų” rinkoje tyrimams. Žinių ekonomikoje išsilavinę ir nuolat besimokantys darbuotojai yra esminis veiksnys smulkaus ir vidutinio verslo įmonèms siekiant konkurencinio pranašumo. Be atitinkamo mokymo/si, darbuotojų žinios gali pasenti ir tapti nepakankamomis efektyviai atlikti jiems keliamas užduotis. Mokymas/sis smulkaus ir vidutinio verslo ịmonėse gali prisidèti prie darbuotojụ igūdžiu ir kompetencijų vystymosi (pvz., Johnston ir Loader, 2003), o tai darys įtaką įmonès veiklos pelningumo didejjimui (Huang, 2001).

Pagrindinis straipsnio tikslas - nustatyti mokymo/si paslaugų poreikių skirtumus skirtingose smulkaus ir vidutinio verslo sektoriaus įmonėse. Taip pat straipsnyje siekiama atskleisti santyki tarp mokymo/si paslaugų panaudojimo didelèse ir smulkaus bei vidutinio verslo ịmonèse. Straipsnyje siekiama verifikuoti hipotezes:

- mokymo/si paslaugu poreikis didèja priklausomai nuo įmonès dydžio;

- didesnès verslo įmonès turi ịvairesnį poreikị skirtingo tipo mokymo/si paslaugoms;

- $\quad$ prioritetai teikiami mokymo/si paslaugoms smulkaus ir vidutinio verslo įmonėse yra skirtingi priklausomai nuo padalinių dydžių.

Straipsnio naujumą sudaro šie aspektai: pirmiausia nepakanka tyrimy apie mokymo/si paslaugas smulkaus ir vidutinio verslo įmonėse Centrineje Europoje. Antra, negausu tyrimų apie tai, nuo kokių veiksnių priklauso mokymo/si paslaugų pasirinkimas. Apskritai mažai tyrimų atliekama apie žmogiškujjų išteklių valdymą smulkaus ir vidutinio verslo (Kyriakidou, Maroudas, 2010). Viena iš priežasčių yra ta, kad iš esmés žmogiškuju išteklių valdymas labiau siejamas su didelèmis kompanijomis, kurios naudoja ịvairesnes mokymo/si praktikas (Heneman, Tansky ir Camp, 2000; Reid ir Harris, 2002). Taip pat nèra pakankamų ịrodymų apie skirtumus tarp smulkaus ir vidutinio verslo sektoriaus įmonių, pvz., mikro-, mažujų, vidutinių mokymo/si poreikių aspektu.

Straipsnyje taikyta kiekybine tyrimu strategija. Tyrime dalyvavo Pomeranijos regiono (Lenkija) smulkaus ir vidutinio verslo įmonès.

Galima paminèti daugelị priežasčių, kodèl didesnį dèmesi reikia skirti organizaciniam mokymui/si. Kaip teigia O’Regan, Stainer ir Sims (2010), mokymo/si vertė gali būti ir ta, kad šis procesas leidžia paversti žinias efektyviomis veiklomis.

Smulkaus ir vidutinio verslo įmonès turi kreipti dèmesį mokymo/si galimybes dẻl kelių priežasčių:
- $\quad$ joms dažnai trūksta kompetentingų darbuotojų - daugeliu atvejų šio tipo ịmonẻs pralaimi kova dèl talentụ su didesnèmis, siūlančiomis didesnius atlygius ir papildomas, nefinansines motyvacines priemones;

- $\quad$ jos turi nedideles vystymosi galimybes (pvz., patekti i naujas rinkas), priklausomai nuo ịgūdžių ir kompetencijos stokos;

- jos praranda konkurencini pranašumą dèl pakankamų žinių ir igūdžių nebuvimo.

Kaip savo tyrimuose nustate Saá-Pérez, Díaz-Díaz ir BallesterosRodríguez (2012): ,mokymas/sis yra tarsi moderatorius tarp ịmones turimos žiniu bazès ir jos galimybès generuoti naujus produktus". Tai reiškia, kad mokymas/asis gali padèti smulkaus ir vidutinio verslo įmonėms sukurti naujus produktus, integruojant turimus įmonès žiniu išteklius. Ibrahim ir Ellis (2003) teigia, kad mokymas/sis gali padèti pailginti mažos ịmonès gyvavimo ciklą.

Išanalizavus teorinius aspektus, buvo iškeltos atitinkamos hipotezès ir papildomos hipotezès:

H1: Mokymo/si paslaugų panaudojimo galimybės didëja priklausomai nuo įmonès dydžio.

H1a: Didesnès ịmonės dažniau deklaruoja, kad jos naudojo mokymo/si paslaugas praeityje.

H1b:.Didesnès imonès dažniau deklaruoja savo norą naudotis mokymo/si paslaugomis ateityje.

H2:.Didesnès imonès dažniau išreiškia poreiki pagrindiniams mokymo/si paslaugų tipams.

H3: Prioritetai, teikiami ịvairiems mokymo/si paslaugų aspektams smulkaus ir vidutinio verslo įmonėse, ịvairuoja priklausomai nuo dydžio.

H3a: Poreikis ịvairaus tipo mokymo/si paslaugoms skiriasi priklausomai nuo verslo apimčių.

H3b: Mokymo/si paslaugų pasirinkimo priežastys priklauso nuo verslo apimčių.

H3c: Paslaugų teikèjo pasirinkimas įvairuoja priklausomai nuo verslo apimčių.

Duomenys tyrimui gauti iš Pomeranijos ekononomikos apžvalgos 3iojo leidimo. Šioje apžvalgoje yra kaupiami duomenys nuo 2006 -ujjų metų. Tyrimo imtis - 949 įmonés, kurios buvo tirtos panaudojant klausimyną.

Straipsnyje pateikiamos esminès tyrimo išvados.

Pirmiausia didžioji dalis tirtų įmoniu (67 \%) deklaruoja norą naudotis mokymo/si paslaugomis ateityje. Galima daryti išvadą, kad mokymo/si paslaugos nèra labai ịprastos tarp smulkaus ir vidutinio verslo įmonių. Paslaugos pozityviai koreliuoja su įmonès dydžiu - didesnès dažniau deklaruoja, kad jos naudojosi mokymo/si paslaugomis praeityje ir planuoja naudotis ateityje. Didesnès verslo apimtys siejasi su platesniu mokymo paslaugų poreikiu. Tuo pačiu didesnès įmonès ne tik naudojasi mokymo paslaugomis dažniau, bet ir naudoja didesnę jų įvairovę.

Antra, kai įmonès nusprendžia pasinaudoti mokymo paslaugomis, jas skatina labiau ,stūmimo” veiksniai, tokie kaip darbuotojų igūdžių stoka, o ne „traukimo” - pvz., darbuotoju iniciatyvos..Pasirinkdamos mokymo paslaugas, įmonès apsisprendžia atsižvelgdamos ì paslaugos kokybę ir mokymus teikiančios organizacijos vardą.

Trečia, prioritetai teikiami ịvairiems mokymo paslaugų panaudojimo aspektams tarp skirtingo pobūdžio įmonių yra labai panašūs, nerasta jokių reikšmingų skirtumų.

Tyrimas turètu būti atliktas kituose Lenkijos regionuose, taip pat ir kitose šalyse, siekiant palyginti rezultatus ir pateikti universalesnes išvadas.

Reikšminiai žodžiai: mokymo paslaugos, ịgūdžių vystymas, smulkaus ir vidutinio verslo įmonės, Lenkija.

First received: April, 2014

Accepted for publication: May, 2014 